\title{
The use of soft technologies in the care of hypertensive patients in Family Health Strategy*
}

O emprego das tecnologias leves no cuidado ao hipertenso na Estratégia Saúde da Família El empleo de las tecnologías leves en el cuidado al hipertenso en la Estrategia Salud de la Familia

\author{
Geanne Maria Costa Torres ${ }^{1}$ (i) \\ Inês Dolores Teles Figueiredo ${ }^{1}$ \\ José Auricélio Bernardo Cândido ${ }^{1}$ \\ Ana Patrícia Pereira Morais ${ }^{1}$ \\ Maria Irismar de Almeida ${ }^{1}$
}

1. Universidade Estadual do Ceará

Fortaleza, CE, Brasil.
Corresponding author:

Geanne Maria Costa Torres.

E-mail: gmctorres@hotmail.com

Submitted on $10 / 10 / 2017$

Accepted on $04 / 27 / 2018$.

DOI: 10.1590/2177-9465-EAN-2017-0169

\section{Abstract}

Objective: To analyze the use of soft technologies in the care of hypertensive patients in the Family Health Strategy. Method: Descriptive study with qualitative approach. A total of 14 hypertensives and 2 professionals from a Family Health team in a municipality in the interior of the state of Ceará, Brazil, participated in the study in 2016. Data were collected through a checklist for non-participant systematic observation, subsidized by a field diary, being treated by the Thematic Content Analysis. Results: The categories constructed were: Relational technologies in the care of the hypertensive in the FHS and communication process between health-hypertensive professional in the FHS. In care practices permeate soft technologies, relationships; soft-hard, technical knowledge; and hard, the material resources, and verbal communication predominates in interpersonal relationships, to the detriment of nonverbal signals. Conclusion: There is a need to strengthen communication skills and soft technologies to re-signify the production of health care.

Keywords: Health Care; Technology in Health; Hypertension; Family Health Strategy.

\section{Resumo}

Objetivo: Analisar o emprego das tecnologias leves no cuidado ao hipertenso na Estratégia Saúde da Família. Método: Descritivo com abordagem qualitativa. Participaram da pesquisa 14 hipertensos e dois profissionais de uma equipe de Saúde da Família em um município do interior do estado do Ceará, Brasil, em 2016. Os dados foram coletados por um checklist para observação sistemática não participante, subsidiados por um diário de campo, tratados pela Análise de Conteúdo Temática. Resultados: As categorias construídas foram: Tecnologias relacionais no cuidado ao hipertenso na ESF e processo de comunicação entre profissional de saúde-hipertenso na ESF. Nas práticas do cuidado, permeiam as tecnologias leves, as relações; leves-duras, o conhecimento técnico; e duras, os recursos materiais, e a comunicação verbal predomina nas relações interpessoais, em detrimentos dos sinais não verbais. Conclusão: Urge a necessidade de fortalecer as habilidades de comunicação e as tecnologias leves para ressignificar a produção do cuidado em saúde.

Palavras-chave: Cuidados de Saúde; Tecnologia em Saúde; Hipertensão; Estratégia Saúde da Família.

\section{Resumen}

Objetivo: Analizar el empleo de las tecnologías leves en el cuidado al hipertenso en la Estrategia Salud de la Familia. Método: Estudio descriptivo con enfoque cualitativo. Participaron 14 hipertensos y dos profesionales de un equipo de Salud de la Familia en un Municipio del interior del Estado de Ceará, Brasil, 2016. Los datos fueron recolectados por checklist para observación sistemática no participante y diario de campo, tratados por el Análisis de Contenido Temático. Resultados: Emergieron las categorías: Tecnologías relacionales en el cuidado al hipertenso en la ESF y proceso de comunicación entre profesionalhipertenso en la ESF. En las prácticas del cuidado impregna las tecnologías leves, relaciones; leve-duras, conocimiento técnico; y duras, recursos materiales y la comunicación verbal predominan en las relaciones interpersonales, en detrimento del lenguaje no verbal. Conclusión: Es necesario fortalecer las habilidades de comunicación y las tecnologías leves para re-significar la producción de la atención en la salud.

Palabras clave: Prestación de Atención de Salud; Tecnología en Salud; Hipertensión; Estrategia de Salud Familiar. 


\section{INTRODUCTION}

Systemic Arterial Hypertension (SAH) is a serious public health problem in Brazil and in the world. Its prevalence in Brazil varies from $22 \%$ to $44 \%$ for adults (32\% on average), reaching over $50 \%$ for people aged $60-69$ and $75 \%$ among those over 70 years. ${ }^{1}$ When not properly controlled, the risks of complications and the socioeconomic costs arising from incorrect treatments increase.

Professionals from Primary Care (PC) are of primary importance in strategies for the prevention, diagnosis, monitoring and control of arterial hypertension. They should also always focus on the fundamental principle of person-centered practice and, consequently, involve users and caregivers at the individual and collective levels in the definition and implementation of hypertension control strategies. ${ }^{2}$

In Brazil, the reorganization of the care model based on PC, focusing on the Family Health Strategy (FHS) and sedimented under the logic of integral care production, must be permeated by the use of soft technologies that strengthen sensitive listening, bonding, mutual respect, autonomy and reception practices. The $\mathrm{FHS}^{3}$ has driven the production of care by establishing a bond between family and health team, through listening and participation of the user in the planning and interventions of the actions performed, appropriating the use of health technologies that contribute to the autonomy of the user and replace the mechanical and cold act of care.

It is noted, then, that in the FHS the nurse seeks to employ these devices to work a broader approach in health care, with the purpose of better performing and acting in the practices of caring and interpersonal relationships. The care practice ${ }^{4}$ of nurses requires the use of technologies with greater emphasis on relational technologies, since they are essential for a greater dialogue with the users of the health services, enabling the nurse to be able to know their expectations regarding their practices.

It is perceived, then, that the care produced by the professionals who work in the FHS does not always reflects the valorization of these technologies, being outstanding the use of the soft-hard and hard technologies that, in the majority of the times, have not represented a decrease in the prevalence of hypertension and improvement of the quality of life of users. ${ }^{5}$ Linked to this situation, it makes difficult to control pressure levels and reduce complications that compromise the health of hypertensive patients. It is pointed out, therefore, the need of these professionals to appropriate the soft technologies in the production of care, daily, to strengthen the processes related to those who are hypertensive.

Therefore, the approach to this issue is considered an impasse in Public Health, since users with NTCDs, especially hypertensives, reach segments of other health sectors when there is inadequate control of blood pressure levels and impacts significantly on their health and in the work process of those directly involved in the production of care. These developments are presented as challenges to be addressed by health professionals who should promote the soft technologies in the FHS by opening new ways of using communication skills and the production of health care. In view of this, we justify our interest in producing this article, because of the importance of using relational technologies in health production practices.

Soft technologies reveal verbal and non-verbal communication skills, affective bonding ability, and attitudes towards users that improve service quality and resolution. ${ }^{6}$ Communication, when performed effectively, seeks to take on the creation of a link, based on trust and respect, fully serving the person. ${ }^{7}$

Thus, these relational devices should emphasize softhard and hard technologies in the care of the hypertensive, with the purpose of strengthening links, gathering practices that strengthen communication exchanges and interpersonal interactions, substantial in the practices of the reception and humanization of health care.

In the field of health, there is $n 0^{8}$ interaction without communication and both are inherent to care, being skills necessary to be developed for care to take effect. Necessary ${ }^{9}$ is the conscious use of competence in human communication for the well-being of those who need health care, whatever their place of care and the expected results.

In the relational process, the professionals of the FHS, especially the nurse, seek to produce a care based on a clear and understandable communication, directed towards the strengthening of relational technologies and actions that promote health, essential to the production of integral care.

Nursing care should be guided by the ethical dimension and the centrality of the relationship with the other, in order to contribute to the construction of subjective and transformative relationships that provide quality of life to the users in the perspective of integrality of care. ${ }^{4}$ Thus, these professionals should reflect the work of the nurse within the FHS that seeks to conceive improvement in the communication approaches and relational aspect of the interactions to strengthen the production of care of the assisted population.

The relevance of addressing the use of soft technologies in hypertensive care is based on the assertion that this technological apparatus is never sparing, it is always in process, acting mutually at the moment when care is offered to this public. In addition, it is essential to the quality of care provided to SAH users. Based on this premise, this study aimed to: analyze the use of soft technologies in the care of hypertension in the Family Health Strategy.

\section{METHOD}

This is a descriptive study with a qualitative approach, resulting from a dissertation cut, based on a Family Health team, in a municipality in the interior of the state of Ceará, Brazil. 
In the municipality, the process of implementation of Primary Care began in 2000 , gradually replacing the health model that had been in force until then, in order to expand the extension of its coverage, due to the new guidelines directed to the health of the country. Currently, it presents seven Family Health teams $(\mathrm{FHt})$, four Oral Health teams $(\mathrm{OHt})$ and a Family Health Support Center (FHSC), to provide matrix support to the Family Health Strategy teams. It has an estimated population of 16,070 inhabitants and is distant from the Capital of Ceará, Fortaleza, $585 \mathrm{~km}$. It is inserted in the Macroregion of Cariri and in the 20th Microregion of Crato, Ceará

The study population consisted of 14 hypertensive patients and two FHS professionals. For the users, were established as inclusion criteria: being registered in the Health Unit; residing in the area covered by the FHS; having regular monitoring for at least six consecutive months; and exclusion: having cognitive disturbances and being bedridden. The inclusion criterion for the professionals was: acting in the Family Health Strategy for at least one year; and exclusion, being away from work, due to vacation and/or leave.

The data were collected from April to May 2016, using nonparticipant systematic observation, using a checklist containing the groups of therapeutic communication strategies: expression, clarification and validation, ${ }^{9}$ subsidized by a field diary to record the information regarding to observations and other notes perceived in relation to the use of relational technologies. Each participant was observed, on average, for 15 minutes, totaling 210 minutes of recording. To maintain the participants' anonymity, the hypertensive individuals were represented by emotions and feelings, such as joy, lightness, sympathy, concern, among others, according to the conditions in which they were at the moment of the consultations. The professionals were identified by the use of acronyms ( $\mathrm{N}$ - Nurse) and (D - Doctor).

Before data collection, participants were consulted about the interest and availability of participation in the research, being clarified about the objectives and conduction of the study and then invited to sign the Informed Consent Term in two copies, clarifying that they are aware of the purpose of the research and granting the use of the information collected for scientific purposes.

The empirical material derived from observations and the notes in the field diary was coded and analyzed qualitatively, by means of Thematic Content Analysis, ${ }^{10}$ following the three steps: the pre-analysis, which corresponds to the choice of material to be used; exploitation of the material, which consists of the coding operation; treatment of the results obtained and interpretation, which highlights the information obtained, proposes inferences and performs interpretations foreseen in its theoretical framework.

The research project was submitted to the Research Ethics Committee (REC) of the Universidade Estadual do Ceará (UECE), in accordance with the principles of Resolution 466/2012 of the National Health Council/Ministry of Health, which governs the research involving human beings, ${ }^{11}$ obtaining a favorable opinion, according to protocol no $1,506,165 / 2016$ and CAEE: 50475315.5.0000.5534.

\section{RESULTS AND DISCUSSION}

Of the total sample studied, in relation to hypertensive patients, the majority (86.0\%) were female. The extremes of age were 39 to 72 years, being the average 59.5 years. Regarding the marital situation, $57.0 \%$ were married. Almost all of the interviewees $(71.4 \%)$ were illiterate. When it came to health professionals, they had two to four years of professional experience in the Family Health Strategy. Due to these findings in the research, in relation to hypertensive patients, it was observed the need to strengthen the communicative process to minimize health risks from uncontrolled blood pressure, as well as to prevent other cardiovascular diseases. With regard to health professionals, it is necessary that these subjects become aware of and debate about the strengthening of these technologies in the work processes.

Using the Thematic Content Analysis, two categories emerged: relational technologies in the care of hypertensive patients in the FHS and the process of communication between health professionals - hypertensive in the FHS, through the records in the checklist and the cuts considered relevant in the field diary, as a word, a phrase, a gesture, allowing to catalog, reflect and highlight important facts presented in the course of the research, being demonstrated as follows:

\section{Category 1: Relational technologies in the care of hypertensive patients at FHS}

The observations showed that, during the medical and nursing consultations, the practice of care was irrigated with contributory elements to the quality of care provided to hypertensive patients, being permeated by receptive listening, empathy, mutual respect and trust, evidenced by means of harmonious, welcoming and humanized relationships.

In the service we studied, we visualized health professionals who sought to "put themselves in the shoes of others", projecting what they wanted to receive if the situations were contrary, showing affection and understanding, trying to feel what they feel and think what they think. This was evidenced mainly in the Nursing consultations, manifested by the reports:

Lightness - The doctor listens to me [...]

$N$ - You only leave when you finish what you started [...]

Peace - I have high blood pressure today.

$\mathrm{N}$ : Is there a problem? Do you want to tell me what happened? 
So soon, we expose by the speeches favorable attitudes in the health professional interaction of hypertensive patients, through sensitive, empathic, respectful, trustworthy and welcoming listening. Reflecting on these meetings makes it possible to perceive that interpersonal relationships and behaviors in face of the treatment are permeated by a humanized care that directs, in a significant way, the attendance to the needs and priorities of hypertensive patients.

We then assume that the use of soft technologies becomes essential because it strengthens the therapeutic relationship, allowing greater interaction between health professionals and users, contributing positively to the treatment and care directed to hypertensive patients.

In the practice of nursing care, the professional uses these technologies together with the care practices that underpin the profession. In this way, care as inherent to the human being, which considers their needs and helps them to cope with the difficulties of the disease and then to promote their health. ${ }^{12}$

The health service must organize itself to assume its central function of receiving, listening and offering a positive answer, capable of solving the great majority of the health problems of the population, or to be responsible for the answer, even if it is offered in other points of attention of the network. ${ }^{13}$ Thus, the use of soft technologies in health services makes it possible to carry out work that considers the singularities and subjectivities of those involved in the health work process, and should be used by all FHS professionals, both individual, as collectively.

The professional who moves through the ethic of care walks with the person he cares for, making coexist during the encounters the technique, effectiveness and efficacy in a climate of empathy and care to promote the patient's health. ${ }^{14}$ From this perspective, the empathic communication by the Nurse is revealed, valuing the hypertensive as an active subject in the production of self care, in the promotion of autonomy and in the independence to carry out the practices of caring. Empathy ability ${ }^{9}$ is closely related to the feelings of trust, emotional involvement, and mutual respect that occur in interpersonal relationships.

We emphasize in the observations that the situations of "ironies", "scorning", "judgments", "jargons", "blame" and "inattention" of health professionals in the approach to hypertension were not evidenced. We have identified moments of receptive listening, bonding and welcoming, which contribute to a greater interaction between interpersonal interaction, potentializing the production of care..$^{15}$

Innovative forms of care have been developed, with emphasis on qualified listening, a soft technology that involves dialogue, bonding and welcoming relationships.$^{16}$ In a study ${ }^{17}$ carried out in the city of Fortaleza with professionals and users of basic care, it was evidenced that technologies are a way of managing the work in relationships that consequently unveils a bonding interaction, that is, of "bonds" that strengthen the humanized contact between the nursing professional and the service user.

In this sense, we understand the importance of the incorporation of soft technologies in the work processes of professionals working at the FHS, since they enhance the meetings among those involved, strengthen ties and improve health care practices. We expect ${ }^{18}$ that the production of care carried out by FHS professionals will lead to a broader vision of health so that, in their daily practices, integral care can become a reality that is closer to being achieved.

It should also be noted that situations of distress and suffering have been demonstrated in the speeches of hypertensive patients, such as "[...] it has given me a lot of work ... I suffer from this [...]". Even though we perceive in the daily life of the FHS services, a greater demand for nursing services to multi-complainant users, we evidence their concern about the complaints of hypertensive patients, showing solidarity and being sensitive to the reported problems, through a warm and humane assistance.

In the area of care, the use of soft technologies contributes to a planned, effective and quality care. The use of these soft technologies should take control of the production of care, serving as a device for a work logic that values the subjectivities and singularities of the individuals involved in the work process.

Welcoming and humanization recreate possibilities in caring, strengthening bonding, lovingness and interpersonal interaction. The National Humanization Policy ${ }^{20}$ (NHP) proposes a quality service, articulating the technological advances with the reception, promoting the improvement of care environments and the working conditions of the professionals.

Visibly, we observe warm, humanized practices and reflective and experiential moments that improve health care. Nonetheless, we highlight a focus on the disease, prescriptive measures and guidelines for adequate control of hypertension, and advances in the care dimension are necessary. This can be seen in the following narratives:

$D$ - You have received guidelines on how to treat high blood pressure, how to properly take medications, the proper diet and the importance of walking to improve your health.

Peace - Stays quiet, listening to the doctor.

$D-I$ will explain and draw in the prescription the times you should take the medication [...].

$N$ - You, sir, when leaving should pass at the reception desk to schedule an appointment with the physiotherapist. Then go to the hospital to schedule these exams. When you do, come back here to show me.

Through the testimonies, we reiterate that in the unit studied, in the care process, the use of soft-hard and hard technologies 
still prevails, even though there is a relationship with a view to promoting bonding, respect and trust in the interactions of professionals with hypertensives. In this sense, it is necessary to increase the use of soft technologies in the FHS to positively impact on intra and interpersonal relationships and also to collaborate for an integral and individualized care, focusing on the commitment, co-responsibility and self-care of each user.

Therefore, health professionals must use the soft technologies to promote live work in act in order to produce health and provide comprehensive care to users. Working under this perspective strengthens the relational environment and allows the creation of spaces that allow new possibilities in caring practices. Thus, the elements shown in Figure 1 reinforce the importance of soft technologies in the production of care.

Figure 1. Figurative representation of care production. Source: Own elaboration, 2016.

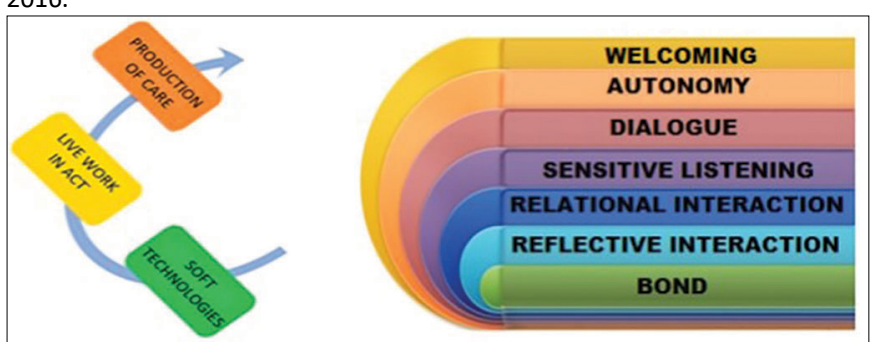

Part of the changes in the production of care lies in the governability of the professionals who work in the Family Health teams, supported by live work in act, since the effectiveness ${ }^{21}$ of the soft technology of living work in health is expressed as 'intercessory relations' which are in the production of work - described as the act of caring - and consumption (of care) occurring at the same time. Therefore, the production ${ }^{17}$ of this type of technology happens at the moment of meeting between the professional and the user in the offer of health services, denominating this production as live work in act.

The use of these soft technologies in cooperation with live work in act is a fundamental support for the production of care, strengthening the bonds, mutual respect and trust, being strengthened by the opening of listening spaces and the creation of warm and humane environments that value the subjectivities and singularities of the hypertensive.

\section{Category 2: Communication process between health professional - hypertensive at FHS}

The verbal communication was present in all moments of health professional interaction of hypertensive patients, according to the following reports:

$N$ - How good! You are doing the diet recommended by the nutritionist.

Joy - Yes, Doctor. And I'm feeling pretty good [...]

\section{Charisma - Doctor, could you see my exams?}

$N$ - Yes, I can [...]. They are good. Congratulations! I wish you much health.

Tranquility - We take the medicine right every day [...].

D: "We"? Whom are you talking about?

Tranquility - My lady and myself.

We then perceive the appreciation of verbal communication among the agents involved to significantly meet the needs and priorities of hypertensive patients. When the communicational process happens in an effective and complete way, it is possible to establish links and to strengthen the bonds with the users, facilitating the diagnosis and appropriate therapeutic measures.

In the field of health, more precisely in the Nursing area, communication is a guiding thread for the promotion of humanized care through a dynamic process that can be expressed by its verbal and/or nonverbal dimensions, involving perception, understanding and transmission of messages. ${ }^{22}$ For communication to be effective, not only verbal but also non-verbal aspects must be taken into account. ${ }^{23}$

In this way, we show that verbal communication is permeated by a therapeutic posture, consuming health care mediated by the constitution of guidelines and interventions that seek to meet the health needs of hypertensive patients.

Considering the importance of communication during the relational process, we observed adequate guidelines by the health professionals, in a welcoming and humanized way, but still in a unidirectional interactivity, as represented in the following narrative:

$D$-You have received guidelines on how to treat high blood pressure, how to properly take medications, proper diet and the importance of walking to improve your health.

Peace - Stay quiet, listening to the doctor.

From the observations in the research unit, we highlight the need of FHS professionals to overcome the challenges expressed in the communication exchanges, seeking to supplant this model that compromises relational technologies. When establishing two-way interpersonal relationships, it contributes to a positive action in the health care provided to hypertensive patients.

Considering interpersonal communication as a bidirectional process that depends on both the sender and the receiver of the message, it is necessary for the professional, when caring for the family, to correctly decode corporal signs of remoteness and insecurity, interpret the silence in an appropriate manner, and is adequately expressed, with open and available body posture, demonstrating security by tone of voice and appropriate choice of words, in a quiet and reserved place. ${ }^{24}$ 
In this line of thought, the urgent need for health professionals in the FHS is to envisage new forms of care, strengthening dialogic relationships between those involved in the process, focusing attention and efforts on the bidirectional communication model.

It is necessary to transform the work process in health with a view to achieving the principles and directives of the Health Unique System, which involves, among other aspects, the need to rebuild the relationship between the subjects who make the daily routine of health services, linked to the process of communication between professionals and users. ${ }^{25}$ The technical and human preparation of the professionals involved is necessary. ${ }^{25}$ The verbal interactions never occur alone, since there is always a dialogue between verbal and nonverbal, and there is no verbal communication alone. ${ }^{29}$

One of the modalities of non-verbal communication present in the observations was paralanguage, demonstrated by grunts "ahhh", "hum", "sighs", accompanied by a docile and quiet interpersonal relationship. In this section, we show that professionals use appropriate voice in the expressed words; however, they need to understand the different situations portrayed by the users, such as coughing, smiling, and silencing, to avoid misunderstandings in the communicative process. ${ }^{15}$

The manifestations of the body such as "moving the arms", "shaking the head", "frown the forehead", were not properly valued during the interactions in the production of care, requiring a different look on the part of health professionals regarding messages can represent anger, anxiety, impatience, fear, among other emblematic expressions.

It is necessary to understand these messages, not only to bring information about people, but also because our body is an important information center. ${ }^{27}$ Understanding them makes the interpersonal relationship more consistent and effective, as it reduces situations of stress, anxiety and other difficulties at the moment the interaction is operationalized. It is on the basis of this interaction with the other that the human being is constituted.

In the people we care for, communication always exists, whether through the look, the expression of their faces, their gestures and their words, or even the way they occupy their environment. ${ }^{28}$ Within this context, the nurse seeks to instrumentalize these modalities of communication to better target the production of care, with a view to meeting the needs of users in all their dimensions, fundamental for the provision of a comprehensive, humane and caring health care.

When dealing with proxemics language, we visualize in the health professional interaction of hypertensive patients represented by a personal distance. The distance established between health professionals and hypertensive people is relevant in communication exchanges, ${ }^{15}$ since attention, looking at the user, observing, respecting differences and strengthening spatial relationships convey trust, security and comfort, fundamental to facilitate interaction.
Contact and face-to-face dialogue contribute to quality care, valuing the hypertensive in their dignity, allowing better knowledge about their real needs and allowing a detailed analysis and adequate follow-up of these users.

In the tacesics language, we show the instrumental touch at the moment of the blood pressure measurement by other professionals of the health team. Demonstrations of support, affection, and comfort were observed during the medical and nursing consultations, but the hug, handshake, touch on the hands, arms and shoulders that demonstrated affective communication exchanges were not present in the observations.

There are several types of touches and one of them is expressive and affective, which has the purpose of showing affection, empathy, support, security and proximity to the person. The instrumental touch constitutes the deliberate physical contact necessary for the performance of a specific task, exemplifying, dressing and injecting a medication. ${ }^{27}$ This artifact in a therapeutic relationship contributes to the establishment of bond, dialogue and care among the subjects involved in the communicative process, providing them with support and security, favoring the elevation of hypertensive self-esteem.

Given this, it is essential to understand, comprehend and value non-verbal communication, since it constitutes an instrument that makes it possible to carry out care based on humanization. ${ }^{22}$ However, the professionals of the research unit need to seize best of this modality of communication to implement adequate measures in the assistance provided to the hypertensive ones, extending the communicational process from the intersubjectivity perspective.

This requires training and disposition, since only the set of signals enables the faithful perception of the message. Recognizing this is necessary since, in order to interpret the other's communication, one must be able to deal with the way one communicates. ${ }^{27}$

In the unit studied, verbal communication still prevails, to the detriment of non-verbal language, which is able to value the other, and its facial, gestural and body expressions. Understanding its essence in professional interaction serves as a support in the care process, intensified by the use of soft technologies that strengthens the potential of the therapeutic relationship.

The moment is urgent for changes by health professionals who carry out their activities in the Family Health Strategy for a new way of understanding the work process in health and the relationships that are established between services, professionals and users.

We reinforce, then, that the health professionals who work in the studied unit need to appropriately take control of the communication skills and the soft technologies to promote changes in the health work, fomenting an effective communication that strengthens the relational process among the subjects involved in the production of health care, both individually and collectively. 


\section{CONCLUSION}

The results of this research pointed out that the production of care is permeated by warm and harmonious relationships, disseminated by the use of technological devices that contribute to the quality of health actions dispensed to hypertensive patients - relational technologies, in particular, by the Nurse, which enhances quality in health practices by its essence in the dimension of humanized care.

In this way of taking care of health, besides the use of soft technologies, we perceive soft-hard and hard technologies in the meetings in the different spaces of the care, evidencing the need of the professionals who work in the FHS to instrument the soft technologies in the living work in act to revitalize the care directed to the hypertensive ones and to strengthen the teamwork, with the intention to produce transformations in the subjects, valuing the singularities and subjectivities of these users.

We also emphasize that, in relation to communication exchanges, professionals use verbal and non-verbal languages in health care practices. The verbal communication was the foundation for strengthening the know-how in health, demonstrated through the support, trust, respect and security among the subjects involved in the relational process. Regarding non-verbal communication, this was evidenced by the instrumental touch at the moments of blood pressure measurement.

Thus, we register the need for professionals to sediment the soft technologies in the FHS, as they open paths that enhance the skills directed to communication and the production of care. We want to emphasize that establishing an approximation between bidirectional communication and soft technologies allows greater efficiency in the actions and services offered by the FHS. Therefore, these tools should be explored by all who work in the PC to broaden the dialogues in the opening of spaces that strengthen the practices of the care and the interpersonal relations.

The study had as a limitation the fact that it was applied only in one health unit of the municipality, making it impossible to reach all of the professionals that work in the FHS and, thus, compare with other larger studies. Being the soft technologies of live work in act on health essential to strengthen the production of care through effective and appropriate communication skills, we intend to maintain the dialogue on the technologies of relations to instigate transformations in the spaces of health care.

It is worth mentioning that this study can bring contributions to teaching and research, allowing to increase the range of knowledge of undergraduates and post-graduates, mainly nursing professionals, who continuously seek to build new knowledge to better act on health practices. In the assistance, it can contribute to the professionals who work in the FHS to appropriate these technological devices to work with new ways of producing health care in the population. It is suggested to carry out other research, considering that this theme still projects many reflections that need to be dissected for a closer approximation between health professional-user and a better understanding of the needs of these users.

\section{REFERENCES}

1. Ministério da Saúde (BR). Secretaria de Atenção à Saúde. Departamento de Atenção Básica. Estratégias para o cuidado da pessoa com doença crônica: Diabetes Mellitus. Brasília (DF): Ministério da Saúde; 2014.

2. Ministério da Saúde (BR). Secretaria de Atenção à Saúde. Departamento de Atenção Básica. Estratégias para o cuidado da pessoa com doença crônica: Hipertensão Arterial Sistêmica. Brasília (DF): Ministério da Saúde; 2013.

3. Nery AA, Carvalho CGR, Santos FPA, Nascimento MS, Rodrigues VP. Saúde da Família: Visão dos usuários. Rev Enferm UERJ (Rio de Janeiro) [Internet]. $2011 \mathrm{Jul} / \mathrm{Sep}$; [cited 2018 May 23]; 19(3):397-402. Available from: http://www.facenf.uerj.br/v19n3/v19n3a10.pdf

4. Santos FPA, Acioli S, Rodrigues VP, Machado JC, Souza MS, Couto TA. Nurse care practices in the Family Health Strategy. Rev Bras Enferm [Internet]. 2016 Nov/Dec; [cited 2018 May 23]; 69(6):1124-31. Available from: http://www.scielo.br/scielo.php?script=sci_arttext\&pid $=$ S0034-71672016000601124

5. Almeida JF, Ferreira VSC. O processo de trabalho dos agentes comunitários de saúde na produção do cuidado aos hipertensos na estratégia saúde da família. In: Franco TB, Andrade CS, Ferreira VSC, eds. A produção subjetiva do cuidado: cartografias da estratégia saúde da família. São Paulo: Hucitec; 2009.

6. Ceron M. Habilidades de comunicação: abordagem centrada na pessoa Módulo Psicossocial. Especialização em Saúde da Família. UNA-SUS UNIFESP, 2011. [cited 2015 Sep 20]. Available from: http://www.unasus. unifesp.br/biblioteca_virtual/esf/1/modulo_psicossocial/Unidade_17. pdf

7. Santos LNM, Pedrosa JID, Rodrigues IDCV, Freire MSS, Silva GRF, Luz MHB. Relações interpessoais na Estratégia Saúde da Família: reflexo na qualidade dos cuidados de enfermagem. Rev enferm UFPE On Line (Recife) [Internet]. 2014 Jan; [cited 2018 May 23]; 8(1):155-9. Available from: file:///C:/Users/susana/Downloads/9618-17487-1-PB.pdf

8. Broca PV, Ferreira MA. Communication process in the nursing team based on the dialogue between Berlo and King. Esc Anna Nery [Internet]. 2015 Jul/Sep; [cited 2017 Jan 12]; 19(3):467-74 Available from: http://www.scielo.br/scielo.php?script=sci_arttext\&pid $=$ S1414-81452015000300467

9. Stefanelli MC, Carvalho EC. A contribuição nos diferentes contextos da enfermagem. $2^{\mathrm{a}}$ ed. Barueri: Manole; 2012.

10. Bardin L. Análise de conteúdo. Lisboa: Edições 70; 2011

11. Brasil. Conselho Nacional de Saúde. Resolução № 466, de 12 de dezembro de 2012. Aprova normas regulamentadoras de pesquisas envolvendo seres humanos. Brasília: Diário Oficial da União; 2013.

12. Almeida Q, Fófano GA. Tecnologias leves aplicadas ao cuidado de enfermagem na unidade de terapia intensiva: uma revisão de literatura HU Rev (Juiz de Fora) [Internet]. 2016 Sep/Oct; [cited 2018 May 23] 42(3):191-196. Available from: https://hurevista.ufjf.emnuvens.com.br/ hurevista/article/view/2494

13. Ministério da Saúde (BR). Secretaria de Atenção à Saúde. Departamento de Atenção Básica. Política Nacional de Atenção Básica/Ministério da Saúde. Secretaria de Atenção à Saúde. Brasília (DF): Ministério da Saúde; 2012

14. Zoboli ELCP. Bioética e Atenção Básica: para uma clínica ampliada, uma bioética clínica amplificada. São Paulo, Brasil. Mundo Saúde [Internet] 2009; [cited 2018 May 23]; 33(2):195-204. Available from: https://social. stoa.usp.br/articles/0016/4684/BioA_tica_e_atenA_A_o_bA_sica.pdf

15. Torres GMC. A comunicação terapêutica no cuidado ao paciente hipertenso na estratégia saúde da família [dissertação]. Fortaleza: Universidade Estadual do Ceará, Centro de Ciências da Saúde; 2016. 
16. Maynart $\mathrm{WH}$, Albuquerque $M C$, Brêda $M Z$, Jorge JS. A escuta qualificada e o acolhimento na atenção psicossocial. Acta Paul Enferm [Internet]. 2014; [cited 2017 Feb 12];27(4):300-3. Available from: http:// www.scielo.br/pdf/ape/v27n4/1982-0194-ape-027-004-0300.pdf

17. Oliveira JSB, Suto CSS, Silva RS. Tecnologias leves como práticas de enfermagem na atenção básica. Rev Saúde Com [Internet]. 2017; [cited 2017 Jun 10]; 12(3):613-21. Available from: http://www.uesb.br/ revista/rsc/ojs/index.php/rsc/article/download/379/383

18. Santos FPA, Nery AA, Matumoto S. A produção do cuidado a usuários com hipertensão arterial e as tecnologias em saúde. Rev Esc Enferm USP [Internet]. 2013; [cited 2018 May 23]; 47(1):10714. Available from: http://www.scielo.br/scielo.php?pid=S008062342013000100014\&script=sci_abstract\&tlng=pt

19. Merhy EE. Saúde: a cartografia do trabalho vivo. São Paulo: Hucitec; 2007. $189 \mathrm{p}$.

20. Sanches RCN, Gerhardt PC, Rêgo AS, Carreira L, Pupulim JSL, Radovanovic CAT. Percepções de profissionais de saúde sobre humanização. Esc Anna Nery [Internet]. 2016 Jan/Mar; [cited 2017 Jun 10]; 20(1):48-54. Available from: http://www.scielo.br/pdf/ean/ v20n1/1414-8145-ean-20-01-0048.pdf

21. Sant'Anna SR, Hennington EA. Micropolítica do trabalho vivo em ato, ergologia e educação popular: proposição de um dispositivo de formação de trabalhadores da saúde. Trab Educ Saúde [Internet]. 2011; [cited 2018 May 23]; 9(Suppl.1):223-44. Available from: http://www. scielo.br/scielo.php?pid=S1981-77462011000400011\&script=sci_ abstract\&tlng=es

22. Brito FM, Costa ICP, Costa SFG, Andrade CG, Santos KFO, Francisco DP. Comunicação na iminência da morte: percepções e estratégia adotada para humanizar o cuidar em enfermagem. Esc Anna Nery [Internet]. 2014 Apr/Jun; [cited 2017 Mar 20]; 18(2):317-22. Available from: http://www.scielo.br/pdf/ean/v18n2/1414-8145-ean-18-02-0317. pdf
23. Teston EF, Cecilio HPM, Marques CDC, Monteschio LSF, Sales CA, Marcon SS. Communication towards the terminality process: integrative review. J Nurs UFPE On Line (Recife) [Internet]. 2013 Mar; [cited 2015 Apr 13]; 7(1):803-12. Available from: https://periodicos.ufpe.br/revistas/ revistaenfermagem/article/view/10295

24. Puggina AC, lenne A, Carbonari KFBSF, Parejo LS, Sapatini TF, Silva MJP. Percepção da comunicação, satisfação e necessidades dos familiares em Unidade de Terapia Intensiva. Esc Anna Nery [Internet]. 2014 Apr/ Jun; [cited 2017 Mar 30]; 18(2):277-83. Available from: http://www.scielo. br/scielo.php?script=sci_arttext\&pid=S1414-81452014000200277

25. Bezerra IMP, Machado MFAS, Duarte AS, Costa EAP, Antão JYFL. Comunicação no processo educativo desenvolvido por enfermeiros: as tecnologias de saúde em análise. Saúde Trans Soc (Florianópolis) [Internet]. 2014; [cited 2018 May 23]; 5(3):42-4. Available from: http:// incubadora.periodicos.ufsc.br/index.php/saudeetransformacao/article/ view/2448

26. Damasceno MMC, Zanett ML, Carvalho ECC, Teixeira CRS, Araújo MFM, Alencar AMPG. A comunicação terapêutica entre profissionais e pacientes na atenção em diabetes mellitus. Rev Latino Am Enferm [Internet]. $2012 \mathrm{Jul} /$ Aug; [cited 2018 May 23];20(4):1-8. Available from: http://www.scielo.br/pdf/rlae/v20n4/pt_08.pdf

27. Silva MJP. Comunicação tem remédio: a comunicação nas relações interpessoais em saúde. 8aㅡ. ed. São Paulo: Loyola; 2011.

28. Veríssimo FIL, Sousa PCP. A comunicação como expressão do cuidado humanizado em fim de vida: revisão sistemática. Rev Enferm UFPE On Line (Recife) [Internet]. 2014 Aug; [cited 2018 May 23]; 8(8):2845-53. Available from: https://repositorio.ucp.pt/ bitstream/10400.14/15306/1/6030-60568-1-PB\%20REUOL.pdf. DOI: 10.5205/reuol.6081-52328-1-SM.0808201436

29. Moura MEB, Brito JNPO, Sousa CMM, Ramos CV. A estratégia saúde da família e as tecnologias em saúde: análise reflexiva. Rev Enferm UFPE On Line (Recife) [Internet]. 2014 Jul; [cited 2018 May 23]; 8(7):2155-9. Available from: https://periodicos.ufpe.br/revistas/ revistaenfermagem/article/viewFile/9896/10155

\footnotetext{
* This article is a cut from the Master Thesis titled: "A comunicação terapêutica no cuidado ao paciente hipertenso na Estratégia Saúde da Família", written by Geanne Maria Costa Torres, under the guidance of Profa. Ph.D. Maria Irismar de Almeida. Professional Master's Program in Family Health, from the Northeast Network of Family Health Training - "RENASF", Oswaldo Cruz Foundation - FIOCRUZ/State University of Ceará - UECE, Fortaleza-CE, 2016.
} 